\title{
Multi-use of the white mulberry (Morus alba L.)
}

\author{
"Malgorzata Lochyńska, ${ }^{* *}$ Grzegorz Oleszak
}

*Department of Silkworms Breeding and Mulberry Cultivation, Institute of Natural Fibres and Medicinal Plants, Wojska Polskiego 71b, 60-630 Poznań, Poland e-mail: malgorzata.lochynska@iwnirz.pl

**Experimental Farm in Pętkowo, Institute of Natural Fibres and Medicinal Plants, Pętkowo, 63-000 Środa Wielkopolska, Poland

\begin{abstract}
In 2006 Institute of Natural Fibres and Medicinal Plants (INF\&MP) began research on an old Polish cultivar of white mulberry - "Źółwińska". By that time in Europe the white mulberry had been forgotten or known only as a plant associated with breeding of mulberry silkworms. Nevertheless, the initial studies have shown great potential of this plant in energy, food and pharmaceutical industries. The leaves and fruits contain very valuable active substances, which may be used in health care. What is more, very fast growth of mulberry causes that biomass of the plant may be used as biofuel.

The aim of the article is promoting the white mulberry and presenting its possible various uses, which may be very useful for several sectors of the European economy.
\end{abstract}

Key words: mulberry, energy industry, food industry, active compounds.

\section{Introduction}

Morus alba Linnaeus, 1753 is one of the numerous species in the family Moraceae, which comprises trees, bushes and herbs. Most of the species are native to Asia with warm climate. These plants are characterized with milky sap in shoots. They are both monoecious and dioecious, their flowers are inconspicuous and odorless and the small, sweet fruits are multiple: drupelets or nuts. The leaves are alternately arranged, simple, often lobed and serrated on the margin (Litwińczuk 1993; Butt et al. 2008).

The taxonomy of Morus genus is very complex and complicated because of widespread hybridization, wherein the hybrids are fertile. So far, over 150 species of mulberry have been described, however only 10-16 species are widely recognized by botanists (Datwyler \& Weiblen 2004). All mulberries grow very fast for 40-50 years reaching 60-80 $\mathrm{cm}$ in diameter at breast height, then their growth rate falls. Mulberry tree lives for 200-300 years.

\section{Material and methods}

Present work is based on old, Polish cultivar of white mulberry "Żółwińska", collected from a plantation in Experimental Farm in Pętkowo, INF\&MP. This cultivar was bred in 1950's in Milanówek, near Warsaw, Poland. It characterizes with huge leaves and rapid growth, because "Żółwińska" cultivar was designed for silkworm breeding. The black-coloured fruits of Polish mulberry were used in producing jam and wine.

The energy value of white mulberry "Żółwińska” was examined at the Department of Environment Protection, INF\&MP. The dried annual shoots collected in July 2009 were used in the investigation. The research was carried out in the oxygen bomb calorimeter type KL-5. 


\section{The potential of white mulberry}

There are numerous uses of white mulberry known for centuries. First of all, both white and black fruits were very valuable and sought-after because of their taste and possible use in the kitchen. There are many of recipes for juice, jam, wine, cakes etc. in the literature (Stasiński 1957). The seeds contain $25-35 \%$ of a yellow oil, so mulberry was used as an oil-bearing plant (Sharma \& Madan 1994). What is more, infusion and tea of leaves are healthy because of high content of valuable active compounds. A decoction of leaves is still considered as diaphoretic and emalliorent and applied for gargling in inflammations of throat. The fruits give cooling effect and are used as a laxative, the roots possess anthelmintic activity and astringent properties and the bark is used as a purgative and vermifuge (Sharma \& Madan 1994). However, white mulberry was mainly known for its excellent antidiabetic action. The flavonoids contained in the leaves and bark of mulberry, especially quercetin and 1-deoxynojirimycin (DNJ) lower significantly blood glucose levels by inhibiting enzyme activity, such as: $\alpha$-glucosidases, sucrase and maltase (Oku et al. 2006). Literature data reports that alcoholic extract from the bark, administered to diabetic rats for 10 days, decreased glucose levels by $59 \%$, thereby raising insulin levels by $44 \%$ compared with the control group (Singab et al. 2005). Moreover, protein Moran 20K, derived from the extract of the bark of mulberry roots, has a huge potential for lowering blood sugar levels in streptozotocin-induced mice model with hyperglycemia (Kim et al.1999; Andallu \& Varadacjaryulu 2003; Hansawasdi \& Kawabata 2006).

Concluding, the leaves and bark of mulberry and their components have unique properties useful in the fight against type II diabetes. It has been used in medicine for centuries, and repeatedly new food supplements are created including obtained from the white mulberry, are very popular on the market these days.

However, white mulberry has also other equally important for human health properties. First of all, the leaves and fruits contain $15-31 \%$ high quality protein, crude fiber, 200-300 mg/100g of ascorbic acid, of which over $90 \%$ is present in the reduced form, vitamin B, folic acid, folinic acid and vitamin $\mathrm{D}, \beta$-carotenes and trace minerals (iron, zinc, calcium, potassium, phosphorous, magnesium) (Sharma \& Madar 1994; Srivastava et al. 2006; Ercisli \& Orhan 2007). Moreover, there is a lot of flavonoids (quercetin, rutin, isoquercitrin, astragalin, kuwanon $\mathrm{G}$ and $\mathrm{C}$, catechin, mulberrofuran $\mathrm{G}$, albanol B, morusin, sanggenon $\mathrm{B}$ and D), which exhibit strong antioxidant activity (Yen et al. 1996; Kofujita et al. 2004), antifungal and antibacterial potential against harmful strains of bacteria Bacillus, Staphylococcus, Escherichia and Streptococcus (Shirata 1982; Park et al. 2003) and against viruses Herpes simplex type
1 (HSV-1) (Kimura et al. 2007; Butt et al. 2008). The flavonoids, such as rutin, isoquercitrin, astragalin and quercetin 3-(6-malonylglukoside) and anthocyanins are the most important antioxidants obtained from mulberries (Kim et al. 1999; Doi et al. 2001). What is more, flavones isolated from mulberry leaves show cytotoxic activity against liver cancer cells in rats, human leukemia and melanoma cells in mice (Nam et al. 2002; Kofujita et al. 2004). The polysaccharides from the bark of mulberry roots stimulate lymphocyte proliferation and reduce the production of antibodies (Kim et al. 2000). Both these properties play a significant role in effective treatment against allergies and are currently used in allergic diseases (Butt et al. 2008). In addition, the cyanidin extracted from mulberry fruit protects the brain against endothelial dysfunction and reduces the likelihood of Alzheimer's disease (Serraino 2003). The literature data also reported considerable capacity of mulberry for local whitening of skin, so called depigmentation. The extract from the leaves and bark of mulberry roots causes strong inhibition of DOPA oxidase and exhibits activity against tyrosynase. This in turn inhibits the overproduction of melanin and causes its degradation in local hyperpigmentations (eg. melanoma, ephelide, lentigo) (Iozumi et al. 1993; Fang et al. 2005).

Undoubtedly, one of the most interesting properties of mulberry is the prevention and inhibition of atherosclerosis. The flavonoids (anthocyanins, quercetin) obtained from the white mulberry leaves extract, have strong inhibitory effects on LDL oxidation and increase resistance to blood cholesterol deposits (Chen et al. 2006; Butt et al. 2008). Thus these substances prevent two major causes of atherosclerosis: accumulation of LDL deposits in the vessels and its oxidation. Moreover, the extract from the mulberry bark achieves good results in relieving the state of atherosclerosis, oxidation, aggregation and retention of LDL (Katsube et al. 2006).

The mulberry shows also great potential in fuel and energy production. In India all annual shoots, available after silkworm breeding season, are cut, dried and used as the main renewable source of fuel (Chinnaswamy \& Hariprasad 1995). There is no doubt, that fast-growing mulberry, rich in cellulose $(57.4 \%)$, hemicellulose $(16.3 \%)$ and lignin (24.6\%) (Sharma \& Madan 1994) possess huge energy value - 17.9 MJ/kg (Łochyńska, unpublished data). In addition, the mulberry shows a considerable resistance to disease and pests and has relatively low soil requirements. Mulberry plantations provide a low utilization of productive or degraded agricultural land. Therefore, it may be used to produce heat, electricity and in fuel production: both liquid and gas. These energy crops can be burnt in bulk, or in the form of pellets and briquettes. Moreover, it is possible to obtain 14-17 tones/ha of biomass (Sharma \& Madan 1994; Łochyńska, unpublished data). All these properties of white mulberry show that it may be much 
better than energy willow Salix viminalis, rape straw, mallow Sida hermaphrodita and kenaf Hibiscus cannabinus (Stolarski et al. 2002; Niedziółka \& Zuchniarz 2006; Kołodziej et al. 2007; Burczyk \& Kołodziej 2009). The comparison of energy value of selected materials is given in the Figure 1. The comparison of annual biomass yield is given in the Figure 2.

There are other ways of using this multipurpose tree. Certainly, it may be cultivated as fodder for the mulberry silkworm, which eat only mulberry leaves. It is obvious that high quality of fresh leaves is related with high quality of cocoons. Moreover, mulberry may be used as a natural dyeing plant, because orange-yellow or golden brown wood contains 32\% of tannins (Sharma \& Madan 1994). The mulberry wood is much valued by the sport equipment industry because of its elasticity and flexibility when steamed; it is easy to burnish and varnish. Hockey sticks, tennis and badminton rackets are mainly made form mulberry wood, mulberry planks may be used in the furniture industry - manufacturing furniture, beautiful veneers and wood accessories. The stem bark of white mulberry is very fibrous, so it is used for paper making in China and Europe. It is interesting that first banknotes in ancient China were made from mulberry bark and phloem. The branches and twigs are amazingly flexible. Therefore they are used as binding and cooperage materials, for making baskets and wheels for wood wagons. Furthermore, they may be used as a good substrate for oyster mushrooms Pleurotus sp. (Madan et al. 1992). These fibrous materials, fruits and leaves may be applied as a source of humus, organic fertilizer and soil conditioner or slurry in anaerobic digesters.
Mulberry leaves (not only fruits) are eaten by vegetarians, both leaves and fruits after drying are applied as fodder for birds, reptiles and rodents. In addition, mulberry may be also used in gardening. Young plants formed into dense hedges protect excellently gardens against wind, noise, fumes and rodents. They are also resistant to air pollution. Trimmed mulberry gives no fruits, so may be planted along the sidewalks. What is interesting, sweet fruits of mulberry attract starlings and other birds. It is advisable to plant mulberry near the cherry trees, because some birds choose sweet mulberry fruit instead of cherries. It may be also planted at the field margins - birds, attracted by sweet mulberry fruits, eat pests in adjacent fields.

\section{Conclusions}

White mulberry as a multipurpose plant may be used: in pharmaceutical industry and medicine, in food industry, in energy and fuel industry, in sport equipment industry, in furniture industry, as slurry in anaerobic digesters, as a tanning and dyeing plant, as an oil-bearing plant, in sericology, in paper industry, in production of oyster mushrooms, as organic fertilizer and humus in gardening, as binding and cooperage materials, for making baskets and wooden wheels, as fodder for birds, reptiles and rodents, as treeprotector against pollution, wind, noise, pests, and birds. We hope that this precious plant will be appreciated not only overseas but also in our country and the use of mulberry potential develop several Polish economic sectors.
Figure 1. The energy value of selected, dried plant materials in $\mathrm{MJ} / \mathrm{kg}$ (after Stolarski 2002; Niedziólka 2006; Kołodziej 2007; Burczyk 2009 and own studies)

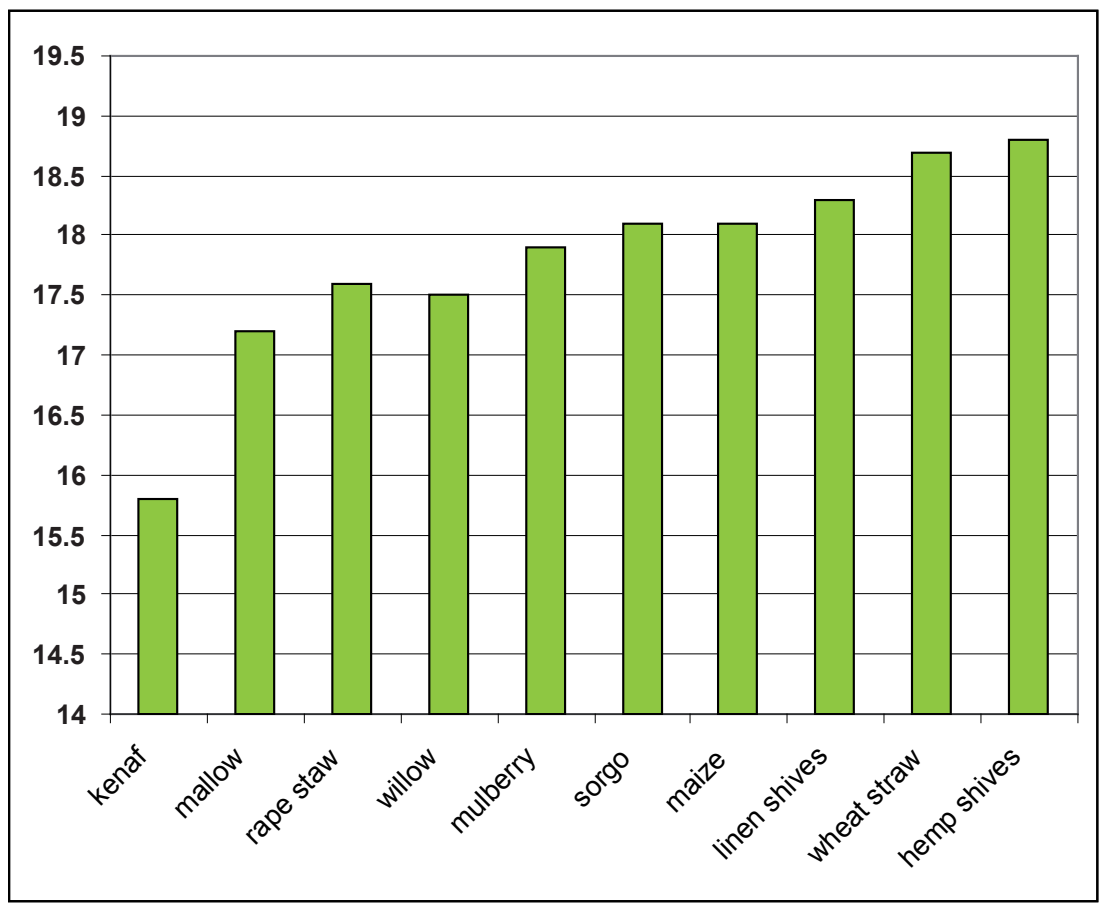




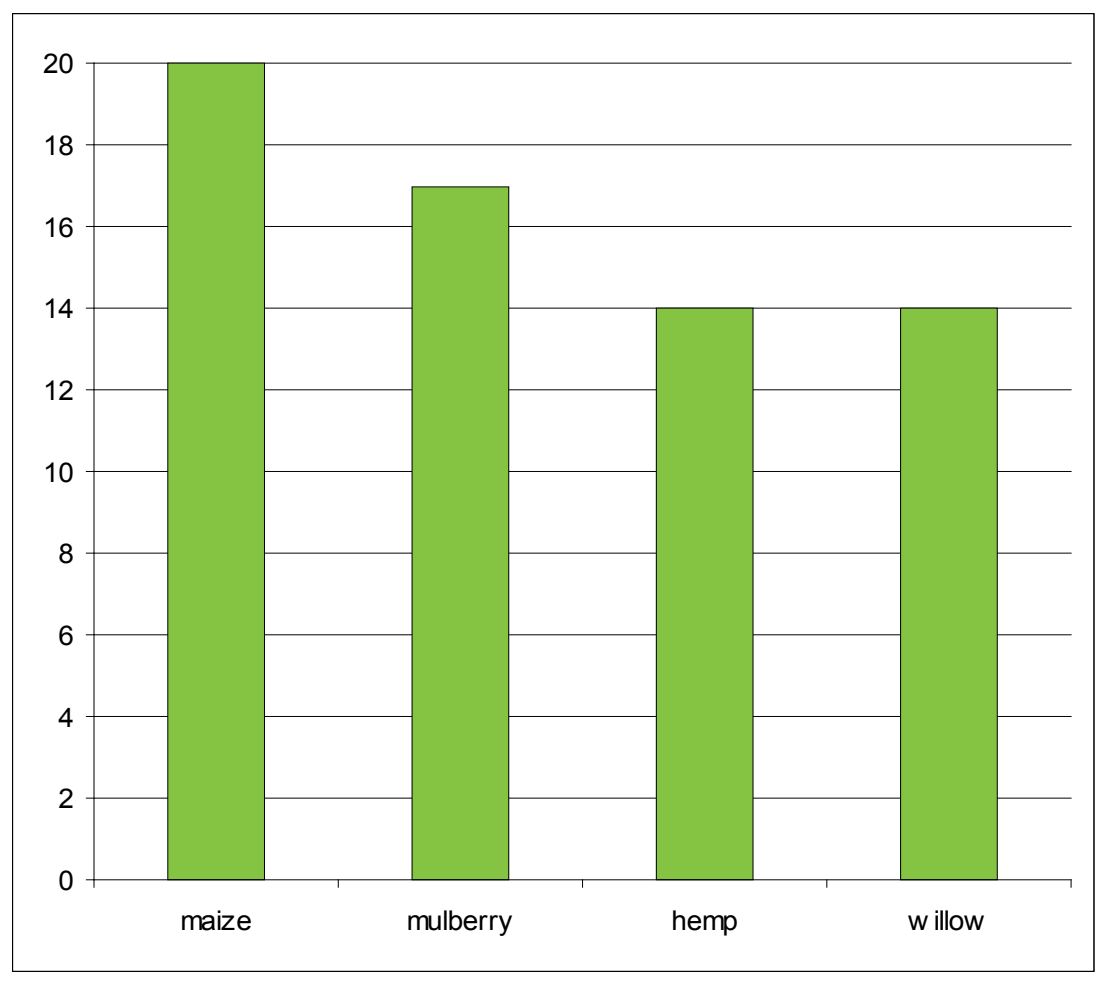

Figure 2. The annual biomass yield of selected plant materials in tones/ha (after Stolarski 2002; Burczyk 2009 and own studies)

\section{References}

Andallu B. \& Varadacjaryulu N., 2003, Antioxidant role of mulberry (Morus indica L. cv. Anantha) leaves in streptozoticin-diabetic rats, Clinica Chimica Acta 338: $3-10$.

Burczyk H. \& Kołodziej J., 2009, Porównanie plonu i wartości energetycznej konopi, kukurydzy i sorga z roślinami egzotycznymi [Comparison of yield and energy value of hemp, maize and sorghum with exotic plants]. Len i Konopie, Biuletyn Informacyjny Polskiej Izby Lnu i Konopi, 12: 22-36 (in Polish).

Butt M.S., Nazir A., Sultan M. T. \& Schoën K., 2008, Morus alba L. nature's functional tonic, Trends in Food Science \& Technology 19: 505-512.

Chen P. N., Chu S. C., Chiou H. L., Kuo W. H., Chiang C. L. \& Hsieh Y. S., 2006, Mulberry anthocyanins cyanidin 3-rutinoside and cyaniding 3-glucoside exhibited an inhibitory effect on the migration and invasion of a human lung cancer cell line, Cancer Letter 235: 248-259.

Chinnaswamy K. P. \& Hariprasad K. B., 1995, Fuel Energy Potentiality of Mulberry, Indian Silk 34 (4): 15-18.
Datwyler S. L. \& Weiblen G. D., 2004, On the origin of the fig: phylogenetic relationships of Moraceae from Ndhf sequences, American Journal of Botany 91(5): $767-777$.

Doi K., Kojami T., Makino M., Kiura Y. \& Fujimoto Y., 2001, Studies on the constituens of the leaves of Morus alba L, Chemical and Pharmacology Bulletin 49: 151-153.

Ercisli S. \& Orhan E., 2007, Chemical composition of white (Morus alba), red (Morus rubra) and black (Morus nigra) mulberry fruits, Food Chem. 103: 1380-1384.

Fang S. H., Hou Y. C. \& Chao P. D., 2005, Pharmacokinetic and pharmacodynamic interactions of morin and cyclosporine, Toxicology and Applied Pharmacology 205: 65-70.

Hansawasdi C. \& Kawabata J., 2006, Alpha-glucosidase inhibitory effect of mulberry (Morus alba) leaves on Caco-2, Fitoterapia 77: 568-573.

Iozumi K., Hoganson G. E., Pennella R., Everett M. A. \& Fuller B. B., 1993, Role of tyrosinase as the determinant of pigmentation in cultures human melanocytes, Journal of Investigative Dermatology 100: 806-811.

Katsube T., Imawaka N., Kawano Y., Yamazaki Y., Siwaku K. \& Yamane Y., 2006, Antioxidant flavanol glycosides 
in mulberry (Morus alba L.) leaves isolated based on LDL antioxidant activity, Food Chemistry 97: 25-31.

Kim S. Y., Gao J. J., Lee W. C., Ryu K. S., Lee R. R. \& Kim Y. C., 1999, Antioxidative flavonoids from the leaves of Morus alba, Archiv der Pharmazie 22: 81-85.

Kim H. M., Han S. B., Lee K. H., Lee C. W., Kim C. Y. \& Lee E.J., 2000, Immunomodulating activity of a polysaccharide isolated from Mori Cortex Radicis, Archives of Pharmacological Research 23: 240-242.

Kimura T., Nakagawa K., Kubota H., Kojami Y., Goto Y. \& Yamagishi K., 2007, Food-grade mulberry powder enriched with 1-deoxynojirimycin suppresses the elevation of postprandial blood glucose in humans, Journal of Agricultural and Food Chemistry 55: 5869-5874.

Kofujita H., Yaguchi M., Doi N. \& Suzuki K., 2004, A novel cytotoxic prenylated flavonoid from the root of Morus alba, Journal of Insect Biotechnology and Sericology 73: 113-116.

Kołodziej J., Mańkowski J. \& Kubacki A., 2007, Właściwości energetyczne przetworzonych odpadów $\mathrm{z}$ lnu i konopi w porównaniu $\mathrm{z}$ innymi surowcami roślinnymi [Energetic properties of the waste processing of flax and hemp in comparison with other plant materials], Len i Konopie, Biuletyn Informacyjny Polskiej Izby Lnu i Konopi 8: 35-43 (in Polish).

Litwińczuk W., 1993, Charakterystyka, rozmnażanie i wykorzystanie morwy białej (Morus alba L.) [Characteristic, propagation and use of white mulberry (Morus alba L.)], Biuletyn Ogrodów Botanicznych 2: 27-35 (in Polish).

Madan M., Sharma S. \& Vasudevan P., 1992, Mineral content of Pleurotus sajor-caju and organic substrates used, Microbios 69(279): 113-118.

Nam S. Y., Yi H. K., Lee J .C., Song C. H. \& Park J. W., 2002, Cortex mori extract induces cancer cell apoptosis through inhibition of microtubule assembly, Archives of Pharmacological Research 25: 191-196.

Niedziółka I. \& Zuchniarz A., 2006, Analiza energetyczna wybranych rodzajów biomasy pochodzenia roślinnego [Analysis of selected types of biomass energy plant], Motorol 8a: 232-237 (in Polish).

Oku T., Hamada M., Nakamura M., Sadamori N. \& Nakamura S., 2006, Inhibitory effects of extractives from leaves of Morus alba on human and rat small intestinal disaccharidase activity, British Journal of Nutrition 95: 933-938.

Park K. M., You J.S., Lee H. Y., Baek N. I. \& Hwang J. K., 2003, Kuwanon G: an antibacterial agent from the root bark of Morus alba against oral pathogens, Journal of Ethnopharmacology 84: 181-185.

Serraino I., Dugo L., Dugo P., Mondello L., Mazzon E. \& Dugo G., 2003, Protective effects of cyanidin-3-Oglucoside from blackberry extract against peroxynitriteinduced endothelial dysfunction and vascular failure, Life Science 73: 1097-1114.

Sharma S. \& Madan M., 1994, Potential of mulberry (Morus alba) biomass, Journal of Scientific and Industrial Research 53: 710-714.

Shirata A., 1982, Antifungal activity of bark pieces of mulberry (Morus alba) cultivar Ichinose shoot and factors causing its change, Annals of the Phytopathological Society of Japan 48: 147-52.

Singab A. N., El-Beshbishy H. A. Yonekawa M., Nomura T. \& Fukai T., 2005, Hypoglycemic effect of Egyptian Morus alba root bark extract: effect on diabetes and lipid peroxidation of streptozotocin-induced diabetic rats, Journal of Ethnopharmacology 100: 333-338.

Srivastava S., Kapoor R., Thathola A. \& Srivastava R. P, 2006, Nutritional quality of leaves of some genotype of mulberry (Morus alba), International Journal of Food Science and Nutrition 57: 305-313.

Stasiński K., 1957, Zbiór i przechowywanie nasion morwy [Collection and storage of seeds of mulberry], Wydawnictwa Instytutu Jedwabiu Naturalnego, Biblioteczka dla praktyków 3 (in Polish).

Stolarski M., Szczukowski S. \& Tworkowski J., 2002, Produktywność klonów wierzb krzewiastych uprawianych na gruntach ornych w zależności od czasu zbioru i gęstości sadzenia [Productivity of clones and shrubby willows grown on arable land depending on the frequency of harvesting and planting den sity], Fragmenta Agronomia 2: 41-48 (in Polish).

Yen G. C., Wu S. \& Duh P. D., 1996, Extraction and identification of antioxidant components from the leaves of mulberry (Morus alba), Journal of Agricultural and Food Chemistry 44: 1687-1690. 